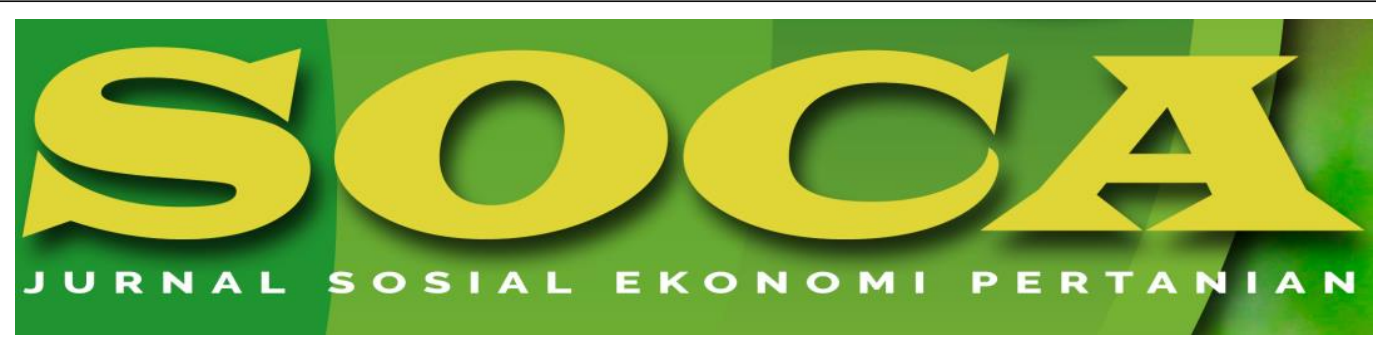

https://ojs.unud.ac.id/index.php/soca

\title{
Adoption of Integrated Crop Management (ICM) Level On Rice Paddy Farming Agricultural Business
}

\author{
Akiyana, Evahelda and Yudi Sapta Pranoto \\ Agribusiness Departement, Agricultural, Fishery, and Biology Faculty \\ Bangka Belitung University, Indonesia. \\ Email:akiansamz@gmail.com, udheisapta@yahoo.com, evaheldaubb@gmail.com \\ Handphone: 0877-6350-8067, 0852-6714-3455, 0813-6770-7791
}

Submitted: 20 November 2019; Revised: 30 December 2019; Accepted: 17 January 2020

Keywords:

Adoption;

Integrated;

Management

\begin{abstract}
Abstrak
Poor level of knowledge and low level of technology adoption can reduce the production of a rice paddy in an agricultural business run by the farmer. Integrated Crop Management (ICM) is an innovation elaborated by the government to deal with these issues. Kepulauan Bangka Belitung Province through the Institute of Agricultural Assessment already implemented ICM to improve the production of crops. The study aims were to describe the Integrated Crop Management (ICM) and to analyze the factors that affected the ICM adoption in agricultural rice paddy business in Rias Village, Toboali District. This study was a survey study conducted in March until June 2019 involving 50 participants from farmer groups who implemented ICM, namely, Sinar Bone and Mekar Berkembang farmer group. Scoring method and multiple linear regression used to analyze the study result. There were three indicators used to describe the ICM level adoption: low, moderate, and high. Statistical analysis showed that the ICM components' adoption level was classified into a high category with a mean of 118.17 points or $78.78 \%$. But on the other side, the component of integrated pest management (IPM) was still classified on the low category with a total of point of 80 or $53.33 \%$. The tillage system component was obtained the highest score with a total of point of 140 or 93.33\%. Factors affected the ICM adoption level were education level, agricultural business experience, agricultural extention and the wide of the agricultural area.
\end{abstract}


How to Cite (APA 6th Style :

Akiyana, Evahelda, \& Pranoto, Y. S. (2020). Adoption of Integrated Crop Management (ICM) Level On Rice Paddy Farming Agricultural Business. SOCA: Jurnal Sosial Ekonomi Pertanian, 14(2), 194-204.

https://doi.org/https://doi.org/10.24843/SOCA.2020.v14.i02.p01

\section{INTRODUCTION}

The implementation of ICM is an effort conveyed to increase the production of food commodities (rice paddy, corn, and soybean) by the agricultural field. Sumarno (2015) stated that ICM is an approach in crop cultivation conducted to improve production and efficiency through a correction and re-organization a location-specific technology component. The ICM implementation is emphasizing in farmer active participation in choosing and evaluating appropriate technology for their biophysical environment, social-cultural, and economic aspect. ICM was specifically implemented based on its location to improve agricultural commodity production.

Technology adoption is a physicological and change of behavior in terms of knowledge, attitude, and action/skill on the technology implementation (Roger and Shoemaker in Hanafi 1981). The decision to adopt an innovation started since they recognize the innovation until they decided to accept or refuse the innovation.

Kepulauan Bangka Belitung Province is an area that developing a rice paddy agricultural field in Indonesia. The wide of the rice paddy field area in Kepulauan Bangka Belitung Province was 25,058 ha and 27,435 ha, while the irrigation system only exists in the 4,234 ha rice paddy field area. Unfortunately, the rice paddy field productivity still classified in a low level, with a total production of 2.30 ton/ha (Kepulauan Bangka Belitung Statistical Institute, 2018), while the national rice paddy field productivity was 5 ton/ha (Indonesia Ministry of Forestry, 2018). Poor level of knowledge and low level of technology adoption is a major factor that contributes to these issues.

As an effort to increase the rice paddy production in Kepulauan Bangka Belitung Province, the Institute of Agricultural Assessment was directed an ICM through a Field School-ICM. Ahmadi (Bangka Belitung 2011, in Fachrista, 2013) stated that the Field School-ICM accompaniment in Bangka Belitung already done in 2009. The Field School accompaniment was conducted in three regencies: Bangka Selatan, Bangka, and Belitung. In 2010, Bangka Belitung Institute of Agricultural Assessment was conducted the Field School-ICM on 60\% Field School-ICM unit in five regencies: Bangka Selatan, Bangka, Bangka Tengah, Belitung, and Belitung Timur. The technology implementation was giving a significant impact on the productivity of the rice paddy field. Before the implementation of the technology, the rice production was 3.48 tons/ha while after the implementation of the technology, the rice production was able to reach 4,58 tons / ha or around 1.1 ton/ha.

Toboali district is an area with the largest rice paddy field in Bangka Selatan Regency with the total of wide of the area of 6,375 ha in comparison with Airgegas District with paddy rice field as wide as 4,071 ha, Lepar Pongok District 104 ha, Payung District 600 ha, Simpang Rimba District 2,350 ha, Tukak Sadai District 0 ha, Pulau Besar District 3,325 ha and Kepulauan Pongok District 25 ha (Bangka Selatan Statistical Institute, 2018).

Institute of Agricultural and Fishery Extention in Toboali District (2018) was stated that rice paddy field which uses irrigation system in Toboali District was only located in Rias Village which involving 43 farmer groups and each group already got an ICM accompaniment through a Field School-ICM which conducted by Bangka 
Belitung Institute of Agricultural Assessment. There were two farmer groups from those farmer group which conducted the ICM. These data showed that ICM did not completely adopt by the farmers.

An effort done by using technology and accompaniment to farmers through a Field School-ICM is relatively limited. A study conducted by Fachrista (2013) showed that the ICM adoption could be affected by some factors: the education level, the wide of the farming area, the accessibility on the farming agricultural business, market, and technological sources. Kariyasa and Dewi (2013) also found that the ICM adoption was affected by age, level of education, productivity, the distance between the farmer's house to the technological sources and the assembly point. This result was contrary to the result of a study done by Sadikin (2011) which stated that socialeconomic factors did not affect the ICM implementation on the farmers. Based on those explanations, the lack of information related to the ICM on the farmers could affect the implementation of ICM in Rias Village, Toboali District. A further study to know the factors that affected the level of technology adoption on the Integrated Crop Management (ICM) on rice paddy farming (Oryza sativa L.) in Rias Village, Toboali District needs to be conducted. The aims of this study were: (1) To describe the level of technology adoption on the Integrated Crop Management (ICM) on the rice paddy farming agricultural bussiness (Oryza sativa L.) in Rias Village, Toboali District and (2) To analyze factors that affected the level of technology adoption on the Integrated Crop Management (ICM) on the rice paddy farming agricultural bussiness (Oryza sativa L.) in Rias Village, Toboali District.

\section{RESEARCH METHODS}

This study conducted in Rias Village, Toboali District, Bangka Selatan Regency in March-June 2019. The purposive sampling technique employed to determine the study location. Rias Village was selected because of two reasons: has the largest agricultural area and has the highest rice paddy productivity in Bangka Selatan.

This was a survey method study. The inclusion criteria used were farmer groups who accepted Field School ICM accompaniment in 2012 and already implemented the ICM. Sinar Bone and Mekar farmer group which consisted of 93 farmers were chosen as the study population based on the inclusion criteria.

Mahmud (2011) stated that the minimum number of a participant in a study using statistical data analysis was 30. Parallel with this statement, Sugiyono (2012) stated that if a study using multivariate analysis (correlation or multiple regression), the number of participants at least must be ten times from the number of variable used in the study. There were 5 variables involved in this study, therefore there were 50 participants required to participate in this study.

The participants chosen to participate in the study were taken from half of the population (50 participants) and able to represent the population used. To represent the two farmer groups: Sinar Bone and Mekar Berkembang, the 25 participants were chosen from each farmer group.

According to the study's aims, the analysis and data processing method are shown in Table 1. 
Table 1. Analysis and Data Processing

\begin{tabular}{llcc}
\hline No. & \multicolumn{1}{c}{ Aims } & $\begin{array}{c}\text { Data } \\
\text { Type }\end{array}$ & $\begin{array}{c}\text { Data } \\
\text { Processing } \\
\text { Method }\end{array}$ \\
\hline 1 & $\begin{array}{l}\text { Describing the level of technology adoption } \\
\text { on the Integrated Crop Management (ICM) on } \\
\text { the rice paddy farming agricultural bussiness } \\
\text { (Oryza sativa L.) in Rias Village, Toboali }\end{array}$ & Primary & $\begin{array}{c}\text { Scorring } \\
\text { Method }\end{array}$ \\
& $\begin{array}{l}\text { District. } \\
\text { Analysing factors that affected the level of } \\
\text { technology adoption on the Integrated Crop } \\
\text { Management (ICM) on the rice paddy farming } \\
\text { agricultural bussiness (Oryza sativa L.) in } \\
\text { Rias Village, Toboali District. }\end{array}$ & $\begin{array}{c}\text { Multiple Linear } \\
\text { Regression }\end{array}$ \\
& : Primary Data, 2019 & \\
Source & & \\
\end{tabular}

The scoring method was used to measure the level of ICM adoption. The impact point which consisted of six basic components of ICM and six optional components of ICM was used to determine the score of the ICM adoption.

The level of ICM adoption classified into three types: low, moderate, and high. The classification is done using the Formula of Sturges to determine the number of class intervals in a data classification (Supranto 2008). The formula of Sturges used was as follow:

Where:

$$
C=\frac{X n-X i}{K}
$$

$\begin{array}{ll}\mathrm{C} & \text { : Class Interval } \\ \mathrm{Xi} & \text { : Minimum Score } \\ \mathrm{Xn} & \text { : Maximum Score } \\ \mathrm{K} & \text { : The number of class }\end{array}$

Table 2 shows the the method used to determine the level of ICM adoption score on rice paddy farmer in Rias Village, Toboali District using adoption level interval class on its each category.

The interval for each category based on the Table 2 is as follows:

1. Adoption level of ICM by the farmer:
a. Low
$: 12-20$
b. Moderate : $21-28$
c. High : $29-36$

2. The level on the basic and the optional $\mathrm{CM}$ adoption:
a. Low
: $6-10$
b. Moderate : $11-14$
c. High
: $15-18$

3. The adoption level of ICM on each component:
a. Low
: $50-83$
b. Moderate : $83-116$
c. High
$: 117-150$

The adoption level of ICM on each component was obtained from the total point from the questionnaire used in this study. The lowest point was 50 and the highest point was 150 with three number of classes. 
Table 2. ICM Adoption Evaluation Category Component

\begin{tabular}{|c|c|c|c|}
\hline No & Variable Indicator (s) & $\begin{array}{c}\text { Minimum } \\
\text { Score }\end{array}$ & $\begin{array}{l}\text { Maximum } \\
\text { Score }\end{array}$ \\
\hline 1. & $\begin{array}{l}\text { Basic Technology Component: } \\
\text { - Superior varieties } \\
\text { - Quality seed } \\
\text { - The use of organic material } \\
\text { - Crop population } \\
\text { - Fertilization } \\
\text { - Integrated Pest Management (IPM) }\end{array}$ & $\begin{array}{l}1 \\
1 \\
1 \\
1 \\
1 \\
1\end{array}$ & $\begin{array}{l}3 \\
3 \\
3 \\
3 \\
3 \\
3\end{array}$ \\
\hline & Total & 6 & 18 \\
\hline 2. & $\begin{array}{l}\text { Optional Technology Component: } \\
\text { - Tillage system } \\
\text { - The use of young seed } \\
\text { - Row planting system } \\
\text { - Effective irrigation } \\
\text { - Weeding technique } \\
\text { - Harvest period and post-harvest } \\
\text { period }\end{array}$ & $\begin{array}{l}1 \\
1 \\
1 \\
1 \\
1 \\
1\end{array}$ & $\begin{array}{l}3 \\
3 \\
3 \\
3 \\
3 \\
3\end{array}$ \\
\hline & $\begin{array}{r}\text { Total } \\
\text { Total } \\
\end{array}$ & $\begin{array}{c}6 \\
12 \\
\end{array}$ & $\begin{array}{l}18 \\
36 \\
\end{array}$ \\
\hline
\end{tabular}

Source : Primary Data, 2019.

The score for the ICM adoption level was obtained from the total of point from the chosen participants. The interval class range was decided using the lowest point (50) and the highest point (150) with the total of the number of the third class.

The percentage of the ICM adoption level was determined as using some steps stated by Ridwan (2004) as follows:

Where:

$$
D P=\frac{n}{N} \times 100 \%
$$

DP : Descriptive Percentage

$\mathrm{n} \quad$ : Score obtained

$\mathrm{N} \quad$ : Maximal score in each component

The multiple linear regression was used to know the correlation between ICM adoption level on rice paddy agricultural bussiness (Oryza sativa L.) and some factors that may effected this adoption level in Rias Village Toboali District. The formula for the multiple linear regression is as follows:

Where:

$$
\mathbf{Y}=\boldsymbol{\beta}_{\mathbf{0}}+\boldsymbol{\beta}_{1} \mathbf{X}_{1}+\boldsymbol{\beta}_{2} \mathbf{X}_{2 \ldots .} \boldsymbol{\beta}_{\mathrm{n}} \mathbf{X}_{\mathrm{n}}+\mathcal{E}
$$

$\mathrm{Y} \quad=$ farmer level of adoption

$\mathrm{X}_{1} \quad=$ age (year)

$\mathrm{X}_{2} \quad=$ agricultural bussiness experience (year)

$\mathrm{X}_{3} \quad=$ the level of education (year)

$\mathrm{X}_{4} \quad=$ agricultural extentions (the frequency of extention meeting happened)

$\mathrm{X}_{5} \quad=$ the size of farming area $(\mathrm{Ha})$

$\beta_{0} \quad=$ constanta

$\varepsilon \quad=$ error 


\section{RESULT AND DISCUSSION}

\section{ICM Adoption Leve1}

Based on the study result, the mean of the ICM adoption was categorized at a high level with a total of a mean of 118.17 or $78.7 \%$. The percentage of the level of adoption on each component means is shown in Table 3.

Table 3. ICM Adoption Level for Each ICM Component in Rias Village 2019

\begin{tabular}{clccc}
\hline No & \multicolumn{1}{c}{ ICM Component } & $\begin{array}{c}\text { The Amount } \\
\text { of Point }\end{array}$ & $\begin{array}{c}\text { Percentag } \\
\text { e (\%) }\end{array}$ & Keterangan \\
\hline 1 & New superior varieties (NSV) & 136 & 90.67 & High \\
2 & Quality seed & 131 & 87.33 & High \\
3 & The used of organic material & 116 & 77.33 & Moderate \\
4 & Crop population & 125 & 83.3 & High \\
5 & Fertilization & 116 & 77.33 & Moderate \\
6 & Integrated pest management & 80 & 53.33 & Low \\
& (IPM) & 140 & 93.33 & High \\
7 & Tillage system & 117 & 78 & High \\
9 & The used of young seed & 130 & 86.67 & High \\
10 & Row planting system & 100 & 66.67 & Moderate \\
11 & Effective irrigation & 100 & 66.67 & Moderate \\
12 & Harvest Period and Post- & & 84.67 & High \\
& Harvest Period & 127 & 78.78 & High \\
\hline \multicolumn{2}{r}{ The Total of Mean } & 118.17 & & \\
Source & : Primary Data, 2019 & & &
\end{tabular}

Table 3 shows that generally, rice paddy farmers in Rias Village are having a good level of knowledge about the importance of ICM adoption in improving their outcome, although not all ICM components already implemented successfully by the farmer. The basic technology component was still categorized on the low and moderate range: the use of organic material (low), integrated pest management (low), and fertilization (moderate). While on the optional component, the effective irrigation and effective weeding were still on a moderate category. This result could be indicated that ICM was not completely adopted in Rias Village.

The level of ICM adoption in Rias Village was affected by the activity of Field School-ICM and agricultural extentions. These methods are still considered effective and efficient in improving the level of technology adoption in the agricultural field.

On the other side, the result showed that the ICM adoption by the farmer in Rias Village was classified in the stable category between the moderate and high categories with the number of the farmer of 25 farmers or $50 \%$. This result could happen due to the level difference of the ICM adopted by the farmer.

\section{The Level of ICM Adoption on the Basic Component}

Based on the result, the majority of the participant $(60 \%)$ were on the high category in adopting the basic component of ICM and $40 \%$ of the participants were on a moderate category in adopting the basic component of ICM.

The highest percentage of components adopted by the farmer was the new superior varieties (NSV) as much as 136 points or $90.67 \%$. The varieties used by the farmer were Mekonga, Ciherang, and Inpari as recommended on ICM. The 
component of the use of material organic and fertilization was still classified on the moderate category with a total of point of 116 or $77.33 \%$. The integrated pest management (IPM) was categorized on the low range with the total points of 80 or $53.33 \%$. The farmer in Rias Village was still using chemical pesticides in their agricultural activities.

The mean of the basic ICM component adoption could be classified on the high category with a value of 117.33 or $78.22 \%$. This result indicated that although the participant couldn't completely adopt the ICM, the participants already understand the importance of basic ICM component adoption on their agricultural activities.

\section{The Level of ICM Adoption on the Optional Component}

Based on the result, 56\% (28 participants) were in a moderate category and $44 \%$ (22 participants) were on a high category in adopting ICM optional component.

The highest optional ICM component adopted by the farmer was the tillage system with a total of point of 140 or $93.33 \%$. While the effective irrigation and efficient weeding still classified on the moderate category with a total point of 100 or $66.67 \%$.

The mean of the basic ICM component adoption could be classified on the high category with a value of 119 or $79.33 \%$. This result indicated that although the participant couldn't completely adopt the ICM, the participants already understand the importance of optional ICM component adoption on their agricultural activities.

\section{Multiple Linear Regression}

Based on the Tabel 4, the regression model obtained was $\mathrm{Y}=0.660+0.000$ $\mathrm{X} 1+0.005 \mathrm{X} 2+0.001 \mathrm{X} 3+0.038 \mathrm{X} 4+0.017 \mathrm{X} 5$. Adjusted R Square Test was 0,697 or 69.7 which means that all the independent variables (age, education level, the experience of agricultural business, agricultural extention, and the size of the agricultural area) can explain the dependent variable with the participation rate of $69.7 \%$, while another $30,3 \%$ was affected by other factors outside the model. Table 4 also showed that the significant value on the $F$ test was $0.000<0.05$. The result of this $\mathrm{F}$ test showed that age, education level, the experience of agricultural business, agricultural extentions, and the size of the agricultural area simultaneously affected that level of ICM adoption. While the $t$ partial test showed that some variables were having a lower value than 0.05 . These results indicated that partially four variables affect the $\mathrm{Y}$ variable (the ICM adoption level on agricultural rice paddy business in Rias Village, Toboali District, they were education (X2), agricultural business experience (X3), agricultural extention (X4) and the agricultural area size (X5). While the variable that did not affect the $\mathrm{Y}$ variable was the age (X1).

Table 4. Multiple Linear Regression Analysis

\begin{tabular}{|c|c|c|c|c|c|c|c|}
\hline \multicolumn{8}{|c|}{ Coefficients } \\
\hline \multirow{2}{*}{ Model } & \multicolumn{2}{|c|}{$\begin{array}{l}\text { Unstandardized } \\
\text { Coefficients }\end{array}$} & \multirow{2}{*}{$\begin{array}{c}\begin{array}{c}\text { Standardized } \\
\text { Coefficients }\end{array} \\
\text { Beta }\end{array}$} & \multirow{2}{*}{$\mathbf{T}$} & \multirow{2}{*}{ Sig. } & \multicolumn{2}{|c|}{$\begin{array}{l}\text { Collinearity } \\
\text { Statistics }\end{array}$} \\
\hline & B & $\begin{array}{l}\text { Std. } \\
\text { Error }\end{array}$ & & & & Tolerance & VIF \\
\hline
\end{tabular}




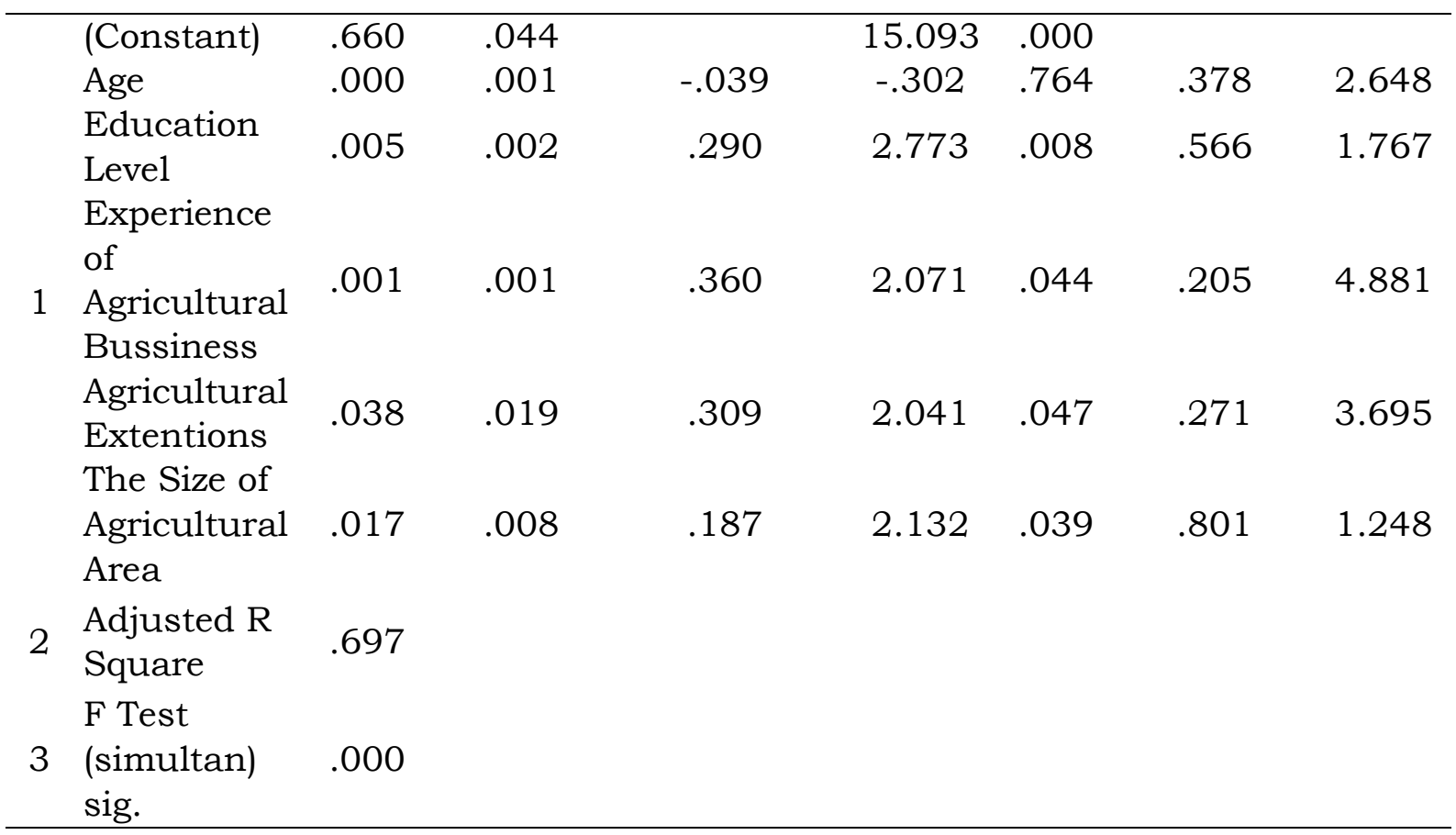

Source: Primary Data, 2019

\section{CONCLUSION}

The conclusion from this study which finds the level of ICM adoption on rice paddy agricultural business in Rias Village Toboali District are: The farmer ICM level of adoption was classified into the highest category with the mean of 118.17 or $78.78 \%$, while the lowest category on the ICM component was integrated pest management (IPM) with the point of 80 or $53.33 \%$. The highest level of ICM adoption in Rias Village Toboali District was the tillage system with the point of 140 or 93.33 $\%$. Factors affected that ICM adoption level on rice paddy agricultural business in Rias Village Toboali District is education level, agricultural business experience, agricultural extention, and the agricultural area size. The value of Adjusted R Square on the multiple linear regression was 0.697 which means that $69.7 \%$ of the ICM adoption level simultaneously affected by education level, agricultural business experience, agricultural extention, and the agricultural area size, while other factors affected the ICM adoption level as much as $30.3 \%$.

\section{RECOMMENDATION}

Based on the result and the discussion, we suggest that:

Some ICM components level of adoption such as IPM, the use of organic material, fertilization, effective weeding, and effective irrigation need to be improved to produce high-quality rice in Rias Village, Toboali District. The farmer group of Bone and Mekar Berkembang need further accompaniment and agricultural extentions to improve their skill and knowledge in increasing the quality of the agricultural products and also providing more spaces for the farmer for agricultural innovation.

The use of chemical pesticides in Rias Village, Toboali District needs to be decreased. The excessive use of chemical pesticides could affect the quality of rice 
harvested. New pest management needs to be implemented. The use of natural predators or organic pesticides is a novel solution that could be implemented in Rias Village, Toboali District. A further study needs to use other independent variables that not explain specifically in this study but could affect the level of ICM adoption on the farmer.

\section{REFERENCES}

AAK. 1990. Budidaya Tanaman Padi. Kanisius. Yogyakarta

Anggi Sahru Romdon. 2012. Kajian Tingkat Adopsi Teknologi Pada Pengelolaan Tanaman Terpadu (Ptt) Padi Sawah (Oryza Sativa L) Di Kecamatan Boja Kabupaten Kendal. Vol 8. No. 1, 2012: hal 42 - 60.

Ahmadi.2011. Diseminasi dan Pengawalan Percepatan Tanam Melalui Pendampingan SL-PTT Padi di Kep. Bangka Belitung. Laporan Akhir Balai Pengkajian Teknologi Pertanian Kepulauan Bangka Belitung. 40 hlm.

Arman. 2004. Faktor-Faktor Yang Mempengaruhi Produktivitas Kerja Peternak Sapi Perah Di Kecamatan Sinjai Barat Kabupaten Sinjai. [Skripsi] Fakultas Peternakan Universitas Hasanuddin Makassar.

Badan Pusat Stastistik.2018. Luas Panen dan Rata-Rata Produksi Padi Sawah Menurut Kabupaten/Kota Provinsi Kepulauan Bangka Belitung 2017.BPS, Provinsi Kepulauan Bangka Belitung

Badan Pusat Stastistik.2018. Potensi luas lahan padi sawah per Kecamatan Bangka Selatan).BPS, Kabupaten Bangka Selatan.

Badan Pusat Stastistik.2018. Jumlah Rumah Tangga Usaha Tanaman Pangan Menurut Jenis Padi per Desa Kecamatan Toboali, 2017 (Ha).BPS, Kecamatan Toboali.

Daniel .2002. Metode Penelitian Sosial Ekonomi. Jakarta : Bumi Aksara

Departemen Pertanian. 2016. Pedoman Umum PTT Padi Sawah. Badan Penelitian dan Pengembangan Pertanian.

Fachrista.Rachmat dan Risfaheri. 2013. Faktor Sosial Ekonomi Penentu Adopsi Pengelolaan Tanaman Terpadu (PTT) Padi Sawah di Bangka Belitung. Vol. 22 No.2, Desember 2013. Balai Pengkajian Teknologi Pertanian Kepulauan Bangka Belitung.hlm113 - 120.

Gujarati. 2003. Ekonomimetrika Dasar, Erlangga, Jakarta.

Hafsah Jafar Mohammad. 2009. Penyuluhan Pertanian Di Era Otonomi Daerah. Jakarta: Pustaka Sinar Harapan.

Umar. 2009. Metode Penelitian untuk Skripsi Dan Tesis Bisnis, Edisi kedua, Rajagrafindo Persada Jakarta. 
Umar. 2011. Metode Penelitian Untuk Skripsi dan Tesis Bisnis Edisi 11. Jakarta: PT Raja Grafindo Persada

Herawati. 2012. Budidaya Padi. Jogjakarta: Javalitera.

Kariyasa,dan Dewi. 2013. Analysis of Factors Affecting Adoption of Integrated Crop Management Farmer Field School (ICM-FFS) In Swampy Areas. International Journal of Food and Agricultural Economics. a1(2): 29-38.

Makarim dan Suhartatik. 2009. Morfologi dan fisiologi tanaman padi. Iptek Tanaman Pangan. Balai Besar Penelitian Tanaman Padi. Sukamandi. 295-330.

Mahmud. 2011. Metode Penelitian Pendidikan. Bandung: Pustaka Setia.

Nawari. 2010. Analisis Regresi dengan Ms Excel 2007 dan SPSS 17. Jakarta : PT. Gramedia.

Pahlevi. 2013. Tujuh Langkah Praktis Pembangunan Basis Data. Elex Media Komputindo. Jakarta.

Phahlevi, R. 2013. Faktor-faktor yang Mempengaruhi Pendapatan Petani Padi Sawah Di Kota Padang Panjang. [Skripsi] Program Studi Ekonomi Pembangunan Universitas Negeri Padang.

Purwono dan Purnamawati, H. 2009. Budidaya 8 Jenis Tanaman Pangan Unggulan. Jakarta : Penebar Swadaya.

Putri, M. 2017. Analisis Efisiensi Penggunaan Faktor Produksi Pada Usahatani Padi Sawah (Oriza Sativa L.) Di Desa Kimak Kecamatan Merawang Kabupaten Bangka. [Skripsi] Mahasiswa Program Studi Agribisnis Universitas Bangka Belitung.

Sadikin dan Banjar. 2011. Analisis Faktor-faktor Sosial Ekonomi yang Mempengaruhi Adopsi PTT Padi Sawah untuk Mendukung kemandirian Pangan beras di Jawa Barat. Pros. Seminar Nasional Implementasi Teknologi Budidaya Pangan menunju Kemandirian Pangan Nasional.. Universitas Muhammadiyah Purwokerto, Purwokerto. hlm. 303 - 316.

Santoso. 2016. Statistika Hospitalitas. Yogyakarta : Deepublish

Santoso, S. 2014. Statistik Parametrik Edisi Revisi. Jakarta : PT Gramedia

Sari, AI., Purnomo, S.H., dan Rahayu, E.T., 2009. Sistem Pembagian Kerja, Akses Dan Kontrol Terhadap Sumber Daya Ekonomi Dalam Keluarga Peternak Rakyat Sapi Potong Di Kabupaten Grobogan. [Skripsi] Universitas Sebelas Maret, Surakarta.

Sumarni. 2014. Perbedaan Peran Laki-Laki dan Perempuan Pada Usaha Sapi Potong di Desa Bentang Kecamatan Galesong Selatan Kabupaten Takalar. [Skripsi] Universitas Hasanuddin Makasar.

Suratiyah, K. 2015. Ilmu Usahatani. Jakarta : Penebar Swadaya. 
Siregar. 1981. Budidaya Tanaman Padi di Indonesia. Sastra Hudaya. Bogor. hlm. 318.

Sumarno dan Kusnadi. 2015. Peningkatan produksi dan efisiensi usahatani jagung melalui penerapan pengelolaan tanaman terpadu (PTT) di Gorontalo. Jurnal Manajemen dan Agribisnis 12(2):79-91.

Sumarno.2017. Faktor Sosial-Ekoomi Yang Mempengaruhi Petani Mengadopsi Inovasi Pengelolaan Tanaman Terpadu Jagung Di Gorontalo. Vol. 26 No.2, Desember 2017. Balai Pengkajian Teknologi Pertanian (BPTP) Gorontalo.hlm. $99-110$.

Supranto. 2008. Statistik: Teori dan Aplikasi. Edisi ke-7.Jakarta (ID): Penerbit Erlangga.

Sugiyono. 2012. Metode Penelitian Kuantitatif Kualitatif dan R\&D. Bandung: Alfabeta.

Sugiyono. 2014. Metode Penelitian Pendidikan Pendekatan Kuantitatif, Kualitatif Dan R\&D. Bandung: Alfabeta.

Rahayu, S.U. 2014. Analisis Pendapatan Keluarga Wanita Sigle Parent. Jurnal Ekonomi Kuantitatif Terapan. Vol 7 No 2, Agustus 2014.

Ratnawaty Siata. 2016. Faktor - Faktor Yang Mempengaruhi Petani Dalam Penerapan Benih Padi Varietas Ciherang Di Desa Pudak Kecamatan Kumpeh Ulu. Volume 18 No. 3 Nopember 2016.

Riduan. (2004). Belajar Mudah Penelitian untuk Guru-Karyawan dan Peneliti Pemula. Bandung: Alfabeta.

Rusmawan., D. Ahmadi, Muzammil, dan Asmarhansyah. 2011. Kajian Teknologi Usahatani Padi di Lahan Sawah Bukaan Baru Bangka Selatan Kepulauan Bangka Belitung. Balai Besar Pengkajian dan Pengembangan Teknologi Pertanian, Bogor.

Teti Tresnaningsih. 2016. Tingkat Penerapan Teknologi Pengelolaan Tanaman Terpadu Pada Usahatani Padi Sawah (Oryza Sativa L.) (Studi Kasus Di Desa Rejasari Kecamatan Langensari Kota Banjar). Agroinfo. Galuh Vol 2 Nomor 2.

Wahyudi dan Hasibuan.2011. Faktor-faktor yang mempengaruhi Adopsi Teknologi Lada. Belitung: Buletin Riset Tanaman Rempah dan Aneka Tanaman Industri 2:65-74.

Wardhana. 2009. Kedudukan Padi Dalam Perekonomian Indonesia Dalam Padi, Inovasi Teknologi dan Ketahanan Pangan. Balai Besar Penelitian Tanaman Padi. Badan Penelitian dan Pengembangan Pertanian. Jakarta.

Widarjono. 2007. Ekonometrika dan Teori Aplikasi. Yogyakarta. Ekonisia FE UIi.

Yamin, S., Rachmach, L.A., Kurniawan, H. 2011. Regresi dan Korelasi dalam Genggaman Anda : Aplikasi dengan Software SPSS, EViews, MINITAB, STATGRAPHICS. Jakarta : Salemba Empat. 